\title{
Monitoring Restoration of the Eastern Usangu Wetland by Assessment of Land Use and Cover Changes
}

\author{
Emiliana John Mwita \\ Department of Geography and Economics, Dar es Salaam University College of Education, Dar es Salaam, \\ Tanzania \\ Email: emmyrh@yahoo.com
}

Received 24 April 2016; accepted 24 June 2016; published 27 June 2016

Copyright (C) 2016 by author and Scientific Research Publishing Inc.

This work is licensed under the Creative Commons Attribution International License (CC BY).

http://creativecommons.org/licenses/by/4.0/

(c) (i) Open Access

\section{Abstract}

Conflicting interests in the use and management of wetlands have always resulted in their degradation. The degradation of wetlands affects their natural functioning, environmental health and livelihood of the people who depend on them. The eastern Usangu wetland has suffered a lot from multiple-use pressure arising from both national and local interests. As a result, the government banned the use of the wetland in $\mathbf{2 0 0 6}$ to support its restoration process. The aim of the current study was to assess the restoration process of the eastern Usangu wetland using time-series Landsat images over a 20-year period, from 1995 to 2015. Cross-tabulation of composite NDVI images was used to examine the changes. The results indicate that the land cover declined by $20 \%$ between 1995 and 2005, and increased by more than $25 \%$ between 2005 and 2015 . The size of the permanent swamp increased consistently, by more than $15 \%$ between 1995 and 2015 . Wetland use has declined to about $15 \%$ over the 20 years. Wetland restoration seems to be a slow process that depends on multiple factors. It thus is important that wetlands are managed well for sustained benefits, rather than waiting to rescue them in a crisis. The well-being of the people depending on the wetlands should be considered when implementing measures to protect the wetlands. Awareness creation among the users, diversification of sources of income and enforcement of the laws and policies governing the use of wetlands by the government may improve status of wetlands.

\section{Keywords}

Tanzania, NDVI, Change Detection, Perennial Swamps 


\section{Background}

Wetland restoration is designed to bring back or re-establish the natural functions and values of wetland ecosystems that have been altered or degraded through the removal of vegetation by cultivation, grazing, burning, construction, filling and grading, and by changes in water levels and drainage patterns. Several other processes taking place outside the wetland area, like deforestation, loss of recharge area, extreme weather conditions, land conversion and changes in local drainage patterns, can severely affect the natural functioning of wetlands. According to [1], the main goal of wetland restoration is to re-establish the hydrology and vegetation back to their original condition or to ensure ecological integrity. Worldwide there is a serious concern about wetland habitat securing and restoration [2]. This is because, in many areas, wetlands have been degraded or overused due to their richness and the diverse ways in which they can accommodate the needs of the ecological environment, local communities and the state at large. However, achieving conservation goals requires serious commitment by the communities concerned and the government.

Remote sensing techniques have now become the most cost-effective method for monitoring and managing wetlands. Remote sensing involves the acquisition of information about the Earth's surface at a remote distance, usually by airplane or satellite [3]. Remote sensing offers tools to map, measure, model and evaluate wetland restoration efforts in a non-invasive, cost-effective manner. Wetlands are often located in remote and sensitive sites and cannot be accessed easily due to their delicate habitat conditions providing shelter for dangerous animals, flooded conditions and thick vegetation. Therefore, remote sensing techniques are particularly helpful to monitor both spatial and temporal trends of wetlands restoration.

The Normalised Difference Vegetation Index (NDVI) is one of the most commonly used vegetation indexes for discriminating between vegetated and non-vegetated areas in environments with low to moderate vegetation cover on light soils or backgrounds [2]-[4], and has been used in change-detection methods [5]-[7]. Furthermore, NDVI can be used to differentiate plant species or growth types, as well as be used as an indicator of plant productivity, which can be correlated with biophysical parameters such as live plant biomass [3]. NDVI has been identified to be one of the most accurate indexes to represent vegetation change compared to other vegetation indexes.

Even though much effort are being done to restore wetlands, post-restoration monitoring is commonly underfunded, understaffed or short term, and the data collected are rarely published [8]. The current study aimed at using NDVI to assess land cover restoration and land use change following government-initiated wetland conservation efforts in Usangu, which is one of the most productive wetlands in the country and, in addition, the mostly affected by anthropogenic factors, not only by the local community of farmers and pastoralists, but also the government's large-scale projects of hydroelectric power production and irrigation activities. Even though the conservation or restoration efforts have been in place for over 40 years, the most prominent decision to protect the wetland was made only in May 2006 [9], when all pastoralists were evicted to other parts of the country [8] [9]. Many studies that have been done since then have assessed the hydrology/water and land management issues [10]-[15], which are one aspect of wetland restoration. Apart from the study done by [11] there is lack of information on land use or cover change in the wetland. This study quantifies land cover restoration and land use change in a time sequence of ten years, from 1995 to 2005 and from 2005 to 2015, using remote sensing approach to uncover the effectiveness of the measures that have been taken to restore the wetland.

\section{The Location and Importance of the Usangu Wetland}

The Usangu wetland lies between longitudes $33^{\circ} 00^{\prime} \mathrm{E}$ and $35^{\circ} 00^{\prime} \mathrm{E}$, and latitudes $8^{\circ} 00^{\prime} \mathrm{S}$ and $9^{\circ} 30^{\prime} \mathrm{S}$ (Figure 1). They are located at the centre of the Usangu Plains and are divided into the western and eastern (also referred to as Ihefu) wetland, which are joined by a narrow band of land along the Great Ruaha River at Nyaluhanga [11]. The total area of the wetland is about $1800 \mathrm{~km}^{2}$, and a larger part of the eastern wetland lies within the Usangu Game Reserve, covering $4148 \mathrm{~km}^{2}$, while the Usangu Plains are located in the southwest of Tanzania.

The Usangu wetlands are amongst the most valuable ecosystems in Tanzania, providing habitat for over 400 bird species and numerous other flora and fauna [10]. Usangu has been a home for more than 300,000 herd of cattle [9] for many years, as pastoralists have found a refuge in the wetland since the late 1960s. These wetlands support numerous small-scale irrigation activities and several large-scale irrigation schemes, particularly in growing paddy, and these feed most of Tanzania and the neighbouring countries with the best quality rice. One of the largest hydroelectric power plants (Mtera Dam) is within the Usangu catchment, as is the Ruaha National 


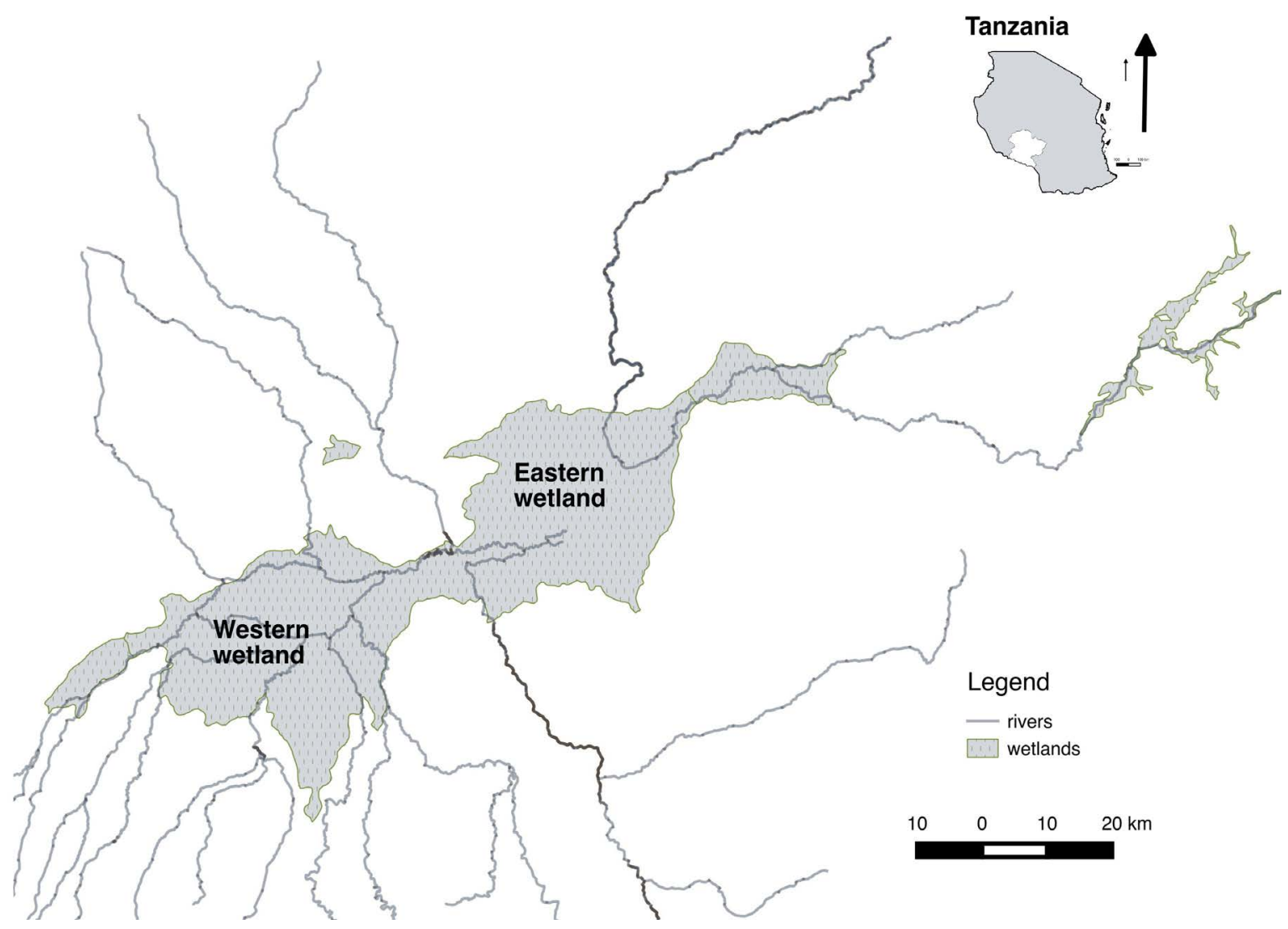

Figure 1. Map of the study area.

Park, which attracts international tourism. Other small-scale economic activities, like fishing, macrophyte harvesting, handicrafts, sand mining and ritual activities, are also common in the wetlands [10] [12]. For many years, Usangu also has received many immigrants from other parts of the country, and in particular agro-pastoralists from Tabora, Mwanza and Shinyanga.

The productivity of the Usangu wetlands and conflicting interests in its utilisation resulted in serious water shortages in various years. In December 1993, the Great Ruaha River upstream of Tanzania's Mtera Dam stopped flowing for the first time in living memory [9]. This matter became a serious national concern in 1995, when critical electricity shortages occurred, leading to power rationing. The blame was laid on various groups of Usangu wetland resource users. The government intervened in 1998 by gazetting the eastern wetland into a new game reserve, and fishermen and livestock keepers were removed [8] [9] [12]. Increasing government concern over power shortages culminated in a mass expulsion in 2006, when livestock keepers were completely evicted from Usangu with their cattle. Apart from the shortage of water, the wetland also was shrinking in size [14]. The dry-season vegetative cover of the Ihefu swamp in the eastern wetland was reported to have decreased by $67 \%$ from 1984 to 2000 [10], and the effect of cattle trampling also contributed to land degradation [13]. It is very important to understand whether or not restoration is taking place and, if so, at what rate. This can be achieved by quantifying the changes, particularly in the eastern part of the wetland, where the swamp has existed over time, to inform policy and decision makers.

\section{Methodology}

The assessment of the land use and cover change (LULC) in the eastern Usangu wetland was done using the NDVI and three software i.e. ENVI (5.3), Erdas imagine (2011) and ArcGIS (10.3) were used for data analysis. NDVI is appropriate for assessing land use and cover of the wetland especially in areas that are not heavily vegetated. The study area has no thick vegetation, hence the index correlates linearly with land cover across the area's radiometric range [16]. Besides measuring the amount of vegetation greenness, the tonal variation 
within the radiometric range of the NDVI bears a near-linear relationship with other surface phenomena, including water bodies and bare land [17]. Cloud cover is a problem when using multispectral datasets (e.g. Landsat) in tropical environments. Cloud cover has low radiometric values in the radiometric range. By extracting maximum radiometric values from each NDVI layer of the same area and creating NDVI composites out of them, clouds can be eliminated [18]. Therefore, NDVI is utilised in LULC studies. Figure 2 below summarizes the process involved in the analysis of LULC for this particular study.

Multi-temporal evaluation of LULC change could be done by using the pixel-based clustering and postclassification tabulation. This involves pixel clustering into themes or classes, and pairwise comparison of variable aerial coverage of the classes between the images. The thematic aerial change involves the transformation of the pairs of pixels from class to class between the image pairs, each representing land cover at a particular time of interest. The principle in this pairwise cross-tabulation is that the thematic maps must cover the same aerial extent, and the number of categories should be the same for each image. Eastman [19] notes that the compared pixels forming the smallest mapping unit should be of the same size. Post-classification cross-tabulation provides unique class values that can be differentiated easily. The output of cross-tabulation includes aerial coverage that has remained unchanged (the diagonal of the cross-tabulation matrix), and that which has changed. In addition, statistics of absolute change and the amount of cover swapped between the changing land cover makes cross-tabulation more useful among other pairwise methods, such as image differencing and rationing. Crosstabulation also works best for an area with limited repetitive datasets. This makes cross-tabulation a better option for multiple-image approaches such as time-series analysis.

The main datasets used for this study were multispectral images, Landsat Thematic Mapper (TM) and Operational Land Imager (OLI) images of the years 1995, 2005 and 2015 (Table 1). The red and near-infrared (NIR) bands were used. The spatial resolution of these was appropriate for differentiating cover classes of interest in the study area. The images are publicly available from the United States Geological Survey website. The datasets used were from the dry season, because this is the period when the boundaries of a permanent wetland can be clearly delineated [20]. Also, the level of disturbance is usually at the maximum, especially as farmers cultivate dry-season crops in dry areas and livestock keepers look for greener pastures [21]. It was important to use dry season data since in wet season cultivation and grazing can take place away from the wetlands because the conditions allows but also most of the areas are vegetated and may complicate the delineation process.

The images were used to generate NDVI composites for each of the study years. Image composites were preferred to singular images for better representation of annual phenomena, and also for cloud masking. The images were re-projected to datum WGS 84 and Zone 36 South, and resampled to a spatial resolution of $30 \mathrm{~m}$ for each pixel. The respective red and near-infrared bands from each image were then radiometrically calibrated to obtain at-sensor radiance pixel brightness. This is important for improved consistency between pixel radiance and the respective phenomena on the surface of the ground. The NDVI (NIR-R/NIR+R) was then computed using the obtained radiance. It was not important to conduct atmospheric correction because the atmosphere in the study

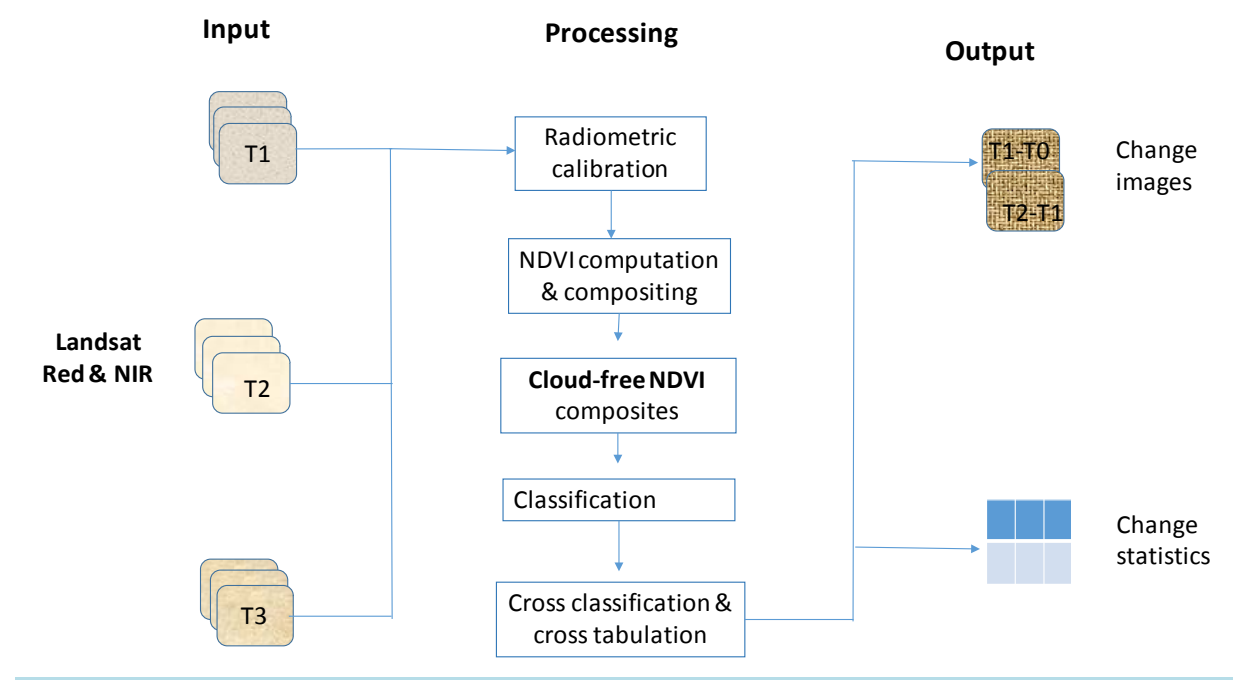

Figure 2. Data processing flow. 
Table 1. Description of datasets used in classification and LULC analysis.

\begin{tabular}{ccccc}
\hline Data type & Date & Path/row & $\begin{array}{c}\text { Red, NIR \& MIR bands Spatial } \\
\text { resolution }\end{array}$ & Producer \\
\hline Landsat TM & June-Nov. 1995 & $169 / 066$ & Band 3 \& 4, 30 m & USGS \\
Landsat TM & June-Nov. 2005 & $169 / 066$ & Band 4 \& 5, 30 m & \\
Landsat OLI & June-Nov. 2015 & $169 / 066$ & & \\
\hline
\end{tabular}

area was clear. The respective NDVIs were made on condition that the resulting composites had to be made up of maximum intersecting pixel values. The resulting composites were delimited to fit to the aerial coverage of the study district, using an edited wetland boundary vector dataset. For editing the interpretation of the Aster GDEM V2 elevation, Landsat datasets, and those of Digital Globe on Google Earth were used.

A hybrid approach combining unsupervised classification and manual aggregation was used. The approach takes advantages of both supervised and unsupervised classification [19]. The NDVI composites were clustered into 30 classes using ISODATA clustering in unsupervised classification. The classes were interpreted and six classes were obtained for each image. The resulting thematic maps were then cross-tabulated to obtain statistics of change, which were processed into land use and cover gain, loss, and total and net absolute change.

\section{Results and Discussion}

\subsection{Land Use Land Cover Classification}

Six main land use and cover categories were identified in the study area (Table 2). These were settlements and other open land, scattered croplands, grassland with scattered croplands, open bushland, seasonally inundated grassland and perennial swamp. More description of the LULC categories is provided in Table 2.

The coverage of each LULC category varied each year (Table 3). In 1995, the major part of the wetland (Figure 3) was covered by open bushland (46.4\%), followed by perennial swamp (20.8\%), seasonally inundated grassland (18.5\%), grassland with scattered cropland (4.4\%), scattered croplands (6.8) and settlement and other open land (3.2\%). The area under human activities i.e. grassland with scattered croplands, scattered croplands and settlement and other open lands in this particular year seemed to be minimal.

In 2005 as indicated in Table 2, generally, cropland seemed to increase by more than 20\%, open bushland decreased by $65 \%$, seasonally inundated grassland increased by $7 \%$ and the swamp increased by $5 \%$. The increase in some uses, like cropland, and decrease in the areas covered by open bushland, indicate that even though the wetland was gazzeted there was still serious encroachment for grazing and cultivation. Figure 4 below displays the LULC of the wetland in 2005.

The LULC in 2015, as indicated in Table 2 and presented in Figure 5, indicates an increase in settlements in the vicinity of the wetland by only $0.9 \%$ compared to 2005 . There was a tremendous decline in scattered cropland compared to 2005 from 16.5\% to only 5.1\%; grassland with scattered cropland decreased from $8.9 \%$ in 2005 to only 3.2\% in 2015; and open bushland increased from 20\% in 2005 to 40.7\% in 2015. Seasonally inundated grassland declined to $6.4 \%$ and the swamp increased by $10.4 \%$.

\subsection{Quantification of Land Use and Land Cover Change}

An overview of the changes detected between 1995 (T0) and 2005 (T1), as well as between T1 and 2015 (T2), is presented in Table 4. A more detailed analysis of the transition matrix derived from and the interpretation using the approach of Pontius et al. [22] follows (Table 5 and Table 6).

Basically, three different categories of change in T0, T1 and T2 can be seen from the table, i.e. increasing, declining and stable. Between T0 and T1, land cover that increased in surface area was that induced by anthropogenic factors. These included settlements and other open land, scattered cropland, and grassland with scattered cropland. The increase is not very stable, however, because scattered croplands, for example, declined significantly between T1 and T2.Settlements and other open land seemed to increase between T0 and T1 also T1 and T2.Open bushland cover was dynamic; it suffered a significant loss between T0 and T1and begun to recover between T1 and T2. Seasonally inundated grassland showed a dynamic trend increasing and then declining. The permanent swamp increased steadily throughout the period covered, i.e. T0 and T1 and T1 and T2, and from T0 
Table 2. LULC categories and their descriptions.

\begin{tabular}{|c|c|c|c|c|}
\hline Category & \multicolumn{2}{|c|}{ Category name } & \multicolumn{2}{|c|}{ Category description } \\
\hline 1 & \multicolumn{2}{|c|}{ Settlement and other open land } & \multicolumn{2}{|c|}{$\begin{array}{c}\text { Scattered, mainly semi-permanent housing structures made of mud and } \\
\text { with thatch roofs, associated with bare soils covered by scattered patches } \\
\text { of dry grass }\end{array}$} \\
\hline 2 & \multicolumn{2}{|c|}{ Scattered croplands } & \multicolumn{2}{|c|}{$\begin{array}{l}\text { Cultivated areas planted with various crops like maize, but widely spaced } \\
\text { with no clear pattern }\end{array}$} \\
\hline 3 & \multicolumn{2}{|c|}{ Grassland with scattered croplands } & \multicolumn{2}{|c|}{$\begin{array}{c}\text { Naturally mixed herbaceous vegetation and grass. The vegetation is } \\
\text { dense and high, although scattered farming and extensive grazing takes } \\
\text { place }\end{array}$} \\
\hline 4 & \multicolumn{2}{|c|}{ Open bushland } & \multicolumn{2}{|c|}{$\begin{array}{l}\text { Areas covered by shrubs and grass; in extended dry season, farming and } \\
\text { grazing may take place }\end{array}$} \\
\hline 5 & \multicolumn{2}{|c|}{ Seasonally inundated grassland } & \multicolumn{2}{|c|}{$\begin{array}{l}\text { Transitional area between permanent swamp and open bushland usually } \\
\text { covered with wetland vegetation species like cyperus. Normally floods in } \\
\text { wet season }\end{array}$} \\
\hline 6 & \multicolumn{2}{|c|}{ Perennial swamp } & \multicolumn{2}{|c|}{ Permanently flooded swamp } \\
\hline \multicolumn{2}{|c|}{ Land cover/use category } & 1995 & 2005 & 2015 \\
\hline \multicolumn{2}{|c|}{ Settlement and other open land } & 3.2 & 6.9 & 7.8 \\
\hline \multicolumn{2}{|c|}{ Scattered croplands } & 6.8 & 15.5 & 5.1 \\
\hline \multicolumn{2}{|c|}{ Grassland with scattered croplands } & 4.4 & 8.9 & 3.2 \\
\hline \multicolumn{2}{|l|}{ Open bushland } & 46.4 & 20.5 & 40.7 \\
\hline \multicolumn{2}{|c|}{ Seasonally inundated grassland } & 18.5 & 21.8 & 6.4 \\
\hline Perennial swamp & & 20.8 & 26.4 & 36.7 \\
\hline
\end{tabular}

Table 4. Land use land cover change between 1995 and 2015 in the eastern Usangu wetland.

\begin{tabular}{|c|c|c|c|c|c|c|}
\hline \multirow{2}{*}{ Land use/cover category } & 1995 (T1) & 2005 (T2) & 2015 (T3) & \multirow{2}{*}{$\begin{array}{c}\text { Diff } \\
\text { T1-T0 }\end{array}$} & \multirow{2}{*}{$\begin{array}{c}\text { Diff } \\
\text { T2-T1 }\end{array}$} & \multirow{2}{*}{$\begin{array}{c}\text { Diff } \\
\text { T2-T0 }\end{array}$} \\
\hline & Area in $\mathbf{k m}^{2}$ & Area in $\mathbf{k m}^{2}$ & Area in $\mathbf{k m}^{2}$ & & & \\
\hline Settlement and other open land & 42.38 & 92.26 & 104.18 & 49.88 & 11.92 & 61.79 \\
\hline Scattered croplands & 89.98 & 206.97 & 67.95 & 116.69 & -139.01 & -22.03 \\
\hline Grassland with scattered croplands & 58.52 & 118.28 & 42.81 & 59.76 & -75.47 & -15.72 \\
\hline Open bushland & 618.52 & 273.46 & 543.06 & -345.06 & 269.61 & -213.10 \\
\hline Seasonally inundated grassland & 246.95 & 290.75 & 85.69 & 43.80 & -205.06 & -161.26 \\
\hline Perennial swamp & 276.93 & 351.42 & 489.73 & 74.49 & 138.31 & 212.80 \\
\hline Total & 1333.29 & 1333.13 & 1333.42 & & & \\
\hline
\end{tabular}

to T2 generally the swamp gained about $15 \%$ from other uses/covers. This indicates some stable recovery and it is a good sign that the wetland is restoring.

Table 5 provides detailed changes between T0 and T1. Open bushland suffered a very significant loss compared to the others, as $398.55 \mathrm{~km}^{2}$ were lost and only $53.9 \mathrm{~km}^{2}$ were gained from other LULC. The larger part of the loss can be attributed to human activities, especially farming and grazing. The Usangu wetland is known for hosting agro-pastoralists who have been migrating for years in search of pasture and land for cultivation [13], and both large-scale and small-scale irrigation farming are common practices [14]. A detailed analysis indicates that more than $75 \%$ of scattered croplands gained from open bushlands. It is also assumed that grazing was taking 
Table 5. The overall change for land use/cover classes in eastern Usangu wetland (in km²), 1995 to 2005.

\begin{tabular}{lccccc}
\hline Land use class & Gross gain & Gross loss & $\begin{array}{c}\text { Total change } \\
\text { (Gain + Loss) }\end{array}$ & $\begin{array}{c}\text { Swap (Total change - } \\
\text { difference of gain } \\
\text { and loss) }\end{array}$ & $\begin{array}{c}\text { Absolute net change } \\
\text { (Total change-Swap) }\end{array}$ \\
\hline Settlement and other open land & 77.34 & 27.40 & 104.74 & 54.80 & 49.94 \\
Scattered croplands & 183.21 & 66.23 & 249.44 & 132.45 & 116.98 \\
Grassland with scattered croplands & 107.16 & 47.42 & 154.58 & 94.85 & 59.73 \\
Open bushland & 53.87 & 398.85 & 452.72 & 107.73 & 344.98 \\
Seasonally inundated grassland & 210.49 & 166.67 & 377.17 & 333.34 & 43.82 \\
Perennial swamp & 119.86 & 45.36 & 165.23 & 90.73 & 74.50 \\
Total & 751.93 & 751.94 & 1503.87 & 813.91 & 689.96 \\
\hline
\end{tabular}

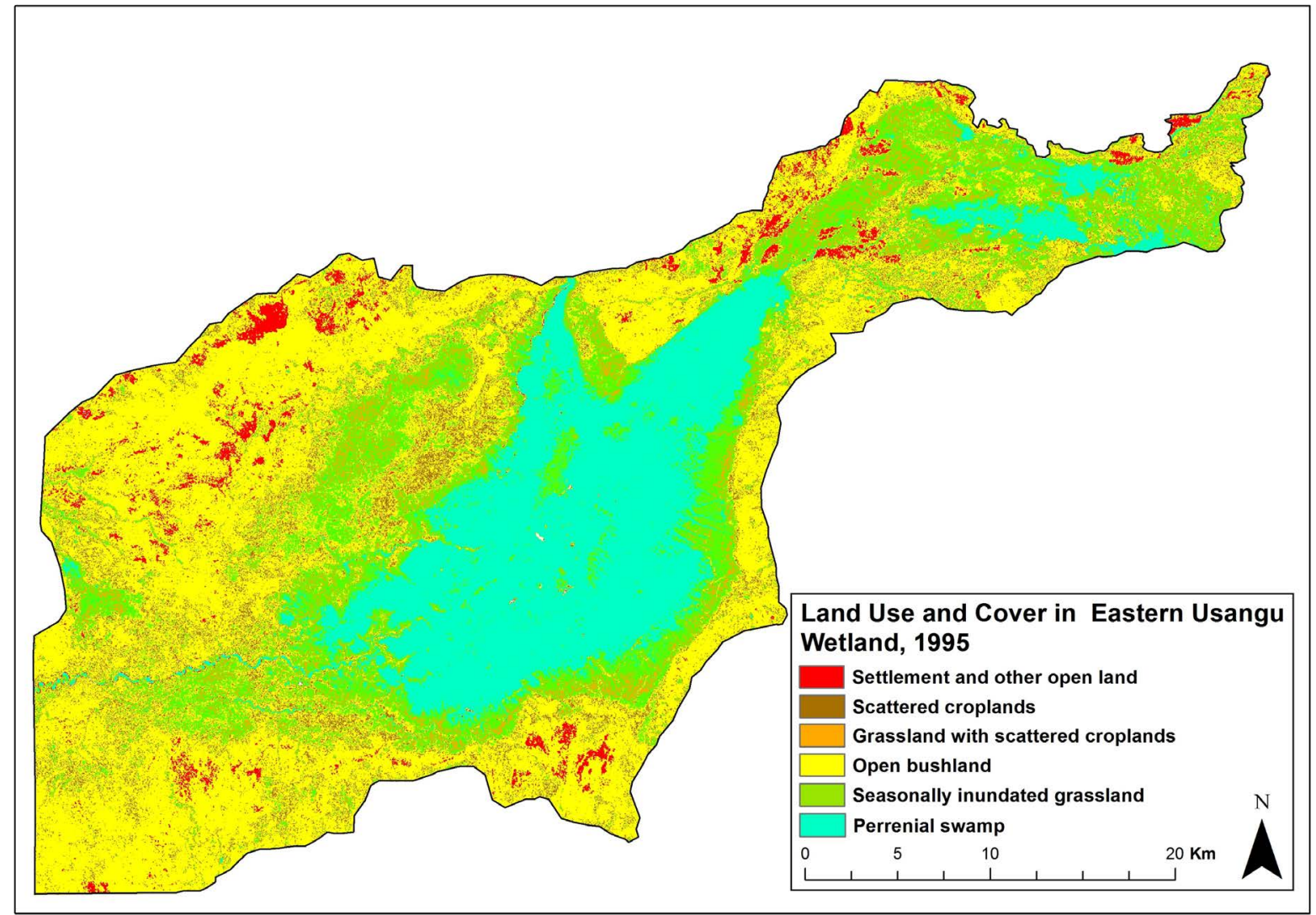

Figure 3. LULC of eastern Usangu wetland, 1995.

place within the bushlands. The grassland with scattered cropland gained $107.16 \mathrm{~km}^{2}$, which is directly related to farming and grazing. Considering that the analysis was based on the dry season, when most of the areas are dry, it is not surprising to find increasing wetland farming due to the availability of moisture in the soil [21] [22]. Increased grazing and farming between 1995 and 1998, among other factors, forced the government to gazette the wetland [9]. Seasonally inundated grassland and perennial swamp increased by $210.49 \mathrm{~km}^{2}$ and $119.86 \mathrm{~km}^{2}$ respectively. About $34.5 \%$ of the loss from open bushland contributed to the gain in seasonally inundated grassland, and $48 \%$ of the loss from this cover was converted to perennial swamp. Perennial swamp indicated the greatest persistence which means that not much of its surface was lost but it gained more from other covers. This generally indicates that, although there still was encroachment in the wetland even after gazetting, the level of 


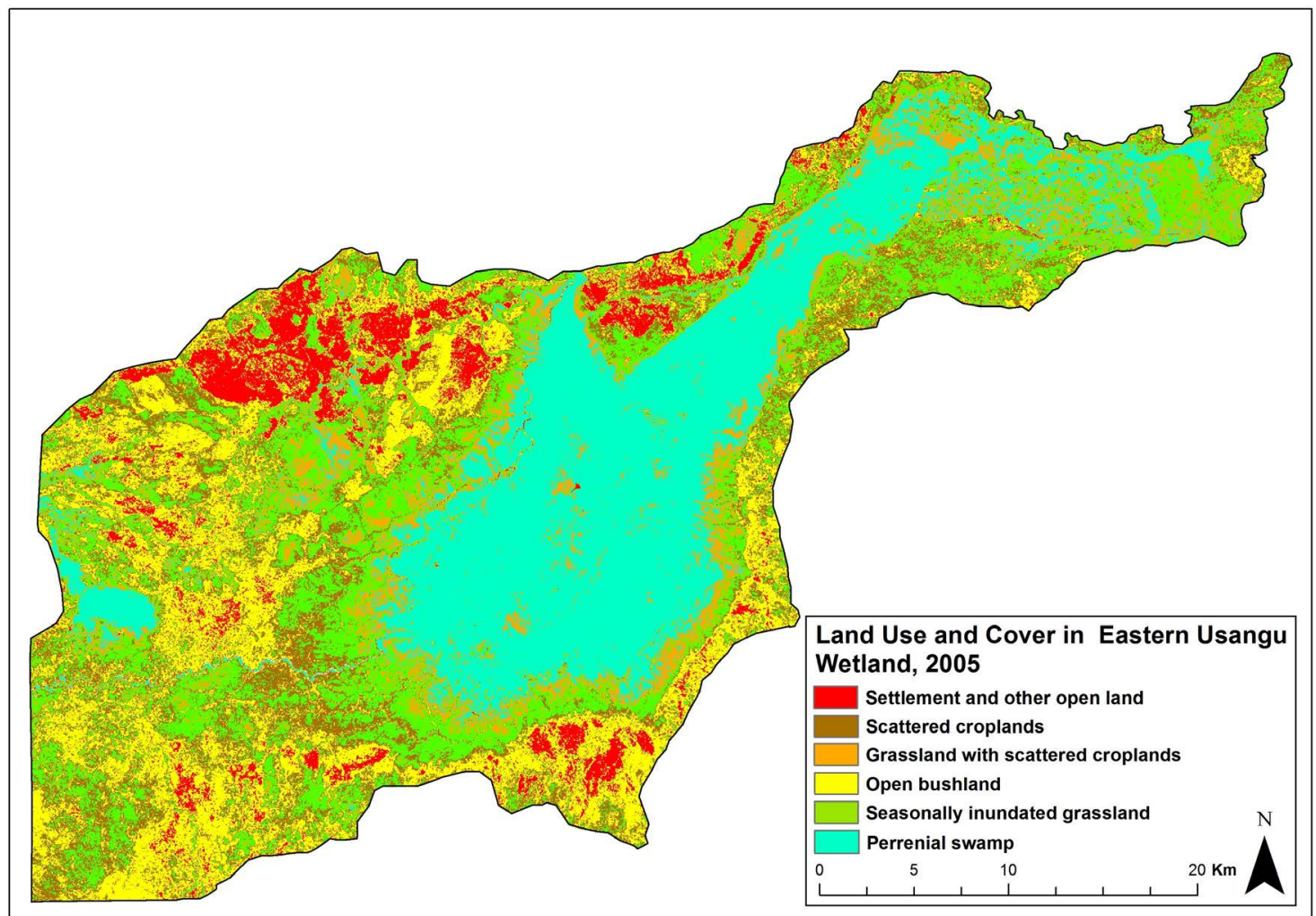

Figure 4. LULC of eastern Usangu wetland in 2005.

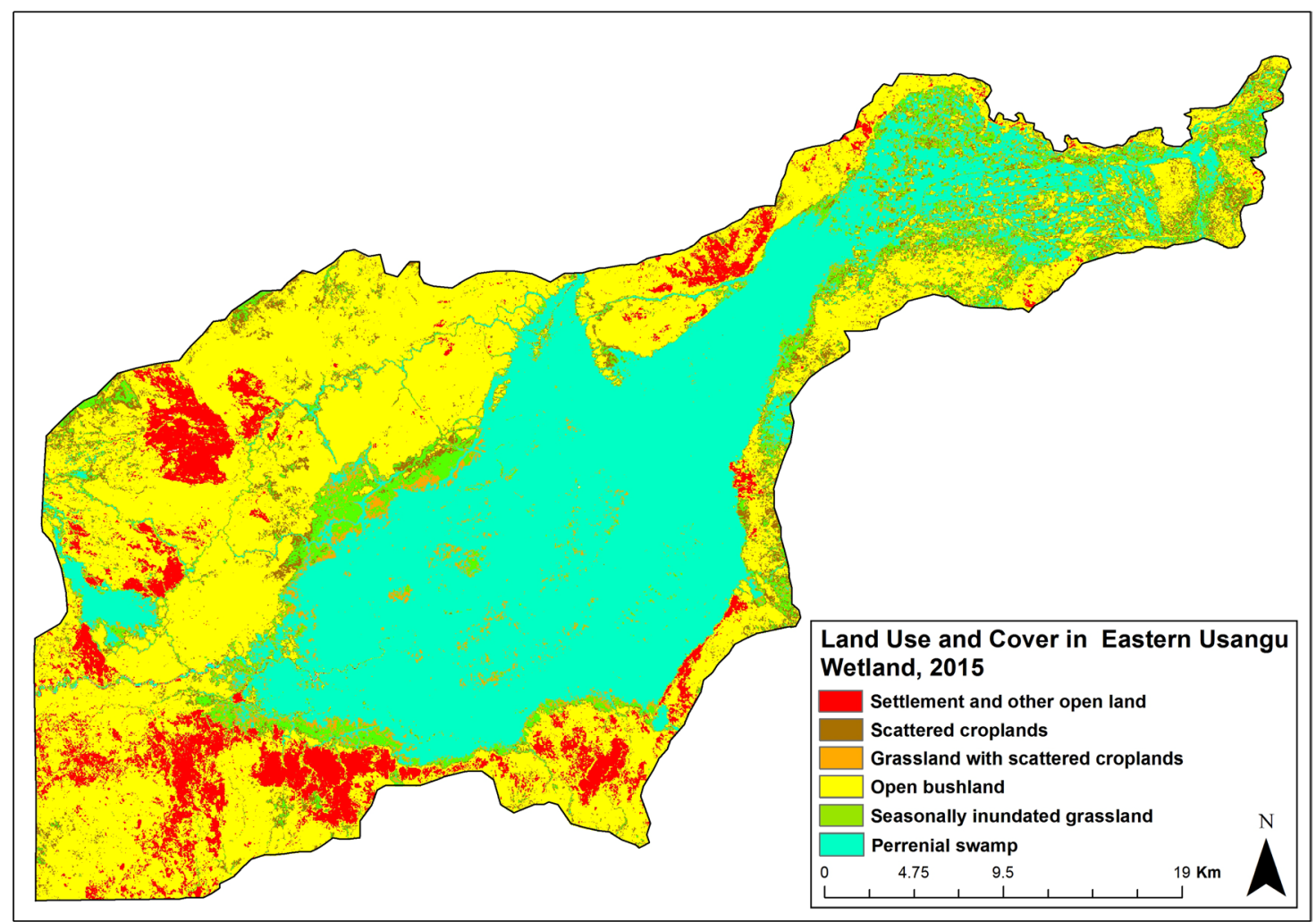

Figure 5. LULC of eastern Usangu wetland 2015. 
disturbance was decreasing slowly.

Significant changes were observed between T1 and T2 (Table 6). While many direct wetland utilisation patterns declined, there was a gain in land cover. Where open bushland, for instance, indicated the highest gain, of $342.81 \mathrm{~km}^{2}$, there proportionally was a great loss of scattered cropland and grassland with scattered croplands (191.66 and $109.96 \mathrm{~km}^{2}$ respectively). As indicated earlier, even after gazetting the eastern Usangu wetland there still was serious encroachment into the wetland for grazing and farming. Grazing, however, was seen to be a greatest threat to the wetland and thus the government banned its use and evicted all the pastoralists in May 2006 [10] [23] [24]. Previous studies of the wetland observed a declining trend in the perennial swamp [10]; in contrast, the current observations indicate that the perennial swamp gained $174.15 \mathrm{~km}^{2}$, compared to the 119.86 $\mathrm{km}^{2}$ of gain between T0 and T1 (almost 145\% gain in 10 years from 2005), and lost only $35.89 \mathrm{~km}^{2}$. Seasonally inundated grassland declined (lost $256.07 \mathrm{~km}^{2}$ ), but it should be noted that the loss that was experienced contributed to a gain in perennial swamp by more than $50 \%$. This part of the wetland is next to the perennial swamp; therefore, since the swamp is gaining more surface it means that part of the seasonally inundated grassland is being converted into permanent swamp. The increase in areas covered by settlement and other open lands does not mean that settlements are increasing, because it can be assumed that even some of the semi-permanent structures that were being used by famers were abandoned after their eviction. It also is possible that farms around those areas have been abandoned. There was a problem in distinguishing the signature between bare land and semi-permanent housing structures built from mud and with thatched roofs. This is a common problem, especially in the dry season, when soils and grass dry out [25].

The consistent increase in perennial swamp by more than $5 \%$ every ten years is proof that restoration is taking place naturally. The permanent swamp has been increasing steadily without a significant loss from 1995 . On the other hand, the declining trend of wetland uses is an indication that the measures taken to protect the wetland are becoming effective. From the results it can be observed that the process of wetlands restoration is slow, as in the period of 20 years only $16 \%$ of the lost parts of permanent swamp were restored. The restoration process depends on a multiplicity of factors, with climate being one of them, thus it is not a linear process. The importance of wetlands management and conservation cannot be overemphasised. The impact of mismanagement of wetlands has been more obvious in eastern Usangu, and without deliberate efforts by the government to protect the wetland it could have been completely depleted by now. The eastern Usangu wetland is not the only wetland under threat in Tanzania. The Lake Victoria wetlands, for instance, have suffered significantly from degradation. Infestation of water hyacinth since the 1990s, resulting from increased nutrients due to pollution from various sources in the lake, illegal fishing practices, farming in the fringes of the wetland and the ever-growing needs of the population continue to threaten the lake ecosystem [26]-[29]. The fish catch and specie varieties have continued to decline, to the extent of affecting the livelihood of the local communities. Degradation of wetlands resources around Lake Nyasa have been reported widely nationally and internationally [30] [31], as well as in the local news [32] [33]. Several other small and large wetlands in rural and urban areas are not used wisely.

Because of the ongoing global climate change, wetlands are becoming even more vulnerable to change [33] and this will make future efforts to restore and manage wetlands more complex. Furthermore, wetland systems are vulnerable to changes in the quantity and quality of their water supply, and it is expected that climate change

Table 6. The overall change in land use/cover classes in the eastern Usangu wetland ( $\left.\mathrm{km}^{2}\right), 2005$ to 2015.

\begin{tabular}{|c|c|c|c|c|c|}
\hline Land use class & Gross gain & Gross loss & $\begin{array}{c}\text { Total change } \\
\text { (Gain + Loss) }\end{array}$ & $\begin{array}{c}\text { Swap (Total change - } \\
\text { Difference of gain } \\
\text { and loss) }\end{array}$ & $\begin{array}{l}\text { Absolute net change } \\
\text { (Total } \\
\text { change-Swap) }\end{array}$ \\
\hline Settlement and other open land & 83.22 & 71.32 & 154.55 & 142.64 & 11.90 \\
\hline Scattered croplands & 52.64 & 191.66 & 244.30 & 105.28 & 139.02 \\
\hline Grassland with scattered croplands & 34.45 & 109.96 & 144.41 & 68.91 & 75.51 \\
\hline Open bushland & 342.81 & 73.31 & 416.11 & 146.61 & 269.50 \\
\hline Seasonally inundated grassland & 50.93 & 256.07 & 307.00 & 101.86 & 205.14 \\
\hline Perennial swamp & 174.15 & 35.89 & 210.04 & 71.79 & 138.25 \\
\hline Total & 738.20 & 738.20 & 1476.40 & 637.08 & 839.32 \\
\hline
\end{tabular}


will have a pronounced effect on wetlands through alterations in hydrological regimes with great global variability. It is therefore important to strengthen measures to conserve and restore wetlands in order to enhance their function and their continued support of people's needs. Efforts to restore wetlands can succeed if there is good co-operation by the local community and government leaders [34]. The pressure of the local population will influence the structure and functions of the wetland ecosystems surrounding them.

Since the laws and policies governing environmental resource use and management are in place, the government should enforce them, the Usangu wetland sets an example in this case. Poor enforcement of policies and laws is one of the factors that has significantly accelerated the degradation of resources in Tanzania. There are many wetland users who do not know the importance of wetlands and how to manage them without jeopardizing their future existence. Awareness creation on wetlands through various media such as radio and Television programs, newspapers and use of extension officers to educate farmers and livestock keepers can also contribute to active involvement and greater public participation in issues related to the conservation and management of wetlands. It also is important to consider diversifying people's means of earning income, especially in the rural areas, in order to reduce their dependence on natural resources. In the case of eviction, as in the case of Usangu, the government should ensure that the destination to which people are being moved is well prepared to receive the incoming population to reduce the risks of the new environment being degraded in the longrun.

\section{Conclusions}

This study investigated the wetland restoration process by using remote sensing to assess the LULC of the eastern Usangu wetland between 1995 and 2015. The results indicate that the restoration is taking place, although very slowly. Between 1995 and 2005, only 5\% of the permanent swamp was restored and wetland encroachment was evident because grazing and farming increased. The permanent swamp continued to increase by $10 \%$ between 2005 and 2015 and at the same period the wetland uses declined tremendously. The vegetation cover increased to for instance open bushland from 21\% in 2005 to $41 \%$ in 2015. These changes would not have happened without deliberate efforts by the government to rescue the wetland after a number of scientific warnings from various scholars on the dangers the wetland was facing. Many wetlands in the country are also threatened by increased and conflicting uses that alter their functioning and reduce their ability to support the environment and people's needs. It is important to ensure that the wetlands are managed wisely for sustained benefit. The role of government in the management of wetland resources is clear, and thus the government is urged to play its part, rather than waiting until conditions become critical.

The current study covered the eastern part of the Usanga wetland and used remote sensing techniques only in assessing the situation based on LULC changes. It will be of interest if further research could be done to assess the restoration process closely by using ecological approaches, including physical field visits. The assessment of other environmental variables that may indicate the trends in changes would be important to inform policy and decision makers, and influence similar efforts in other wetlands encountering similar challenges as the Usangu wetland.

\section{References}

[1] Melesse, A.M., Nangia, V., Wang, X. and McClain, M (2007) Wetland Restoration Response Analysis Using MODIS and Groundwater Data. Sensors, 7, 1916-1933. http://dx.doi.org/10.3390/s7091916

[2] Zedler, J.B. and Kercher, S. (2005) Wetland Resources: Status, Trends, Ecosystem Services, and Restorability. Annual Review of Environmental Resources, 30, 39-74. http://dx.doi.org/10.1146/annurev.energy.30.050504.144248

[3] Jensen, J.R. (2006) Remote Sensing of the Environment: An Earth Resource Perspective. 2nd Edition, Pearson Education, Prentice Hall, Upper Saddle River.

[4] Tuxen, K.A., Schile, L.M., Kelly, M. and Siegel, S.W. (2008) Vegetation Colonization in a Restoring Tidal Marsh: A Remote Sensing Approach. Restoration Ecology, 16, 313-323. http://dx.doi.org/10.1111/j.1526-100X.2007.00313.x

[5] Mwita, E., Menz, G., Misana, S. and Nienkemper, P. (2012) Detection of Small Wetlands with Multi Sensor Data in East Africa. Advances in Remote Sensing, 1, 64-73. http://dx.doi.org/10.4236/ars.2012.13007

[6] Singh, A. (1989) Review Article Digital Change Detection Techniques Using Remotely-Sensed Data. International Journal of Remote Sensing, 10, 989. http://dx.doi.org/10.1080/01431168908903939

[7] D. Lu, Mausel, P., Brondiízio, E. and Moran, E. (2004) Change Detection Techniques. International Journal of Remote Sensing, 25, 2365-2401. http://dx.doi.org/10.1080/0143116031000139863 
[8] Zedler, J.B. (2000) Progress in Wetland Restoration Ecology. Trends Ecological Evolution, 15, 402-407. http://dx.doi.org/10.1016/S0169-5347(00)01959-5

[9] Walsh, M. (2012) The Not-so-Great Ruaha and Hidden Histories of An environmental Panic in Tanzania. Journal of East African Studies, 6, 303-335. http://dx.doi.org/10.1080/17531055.2012.669575

[10] Kashaigili, J.J., Mbilinyi, B.P., Mccartney, M. and Mwanuzi, F.L. (2006) Dynamics of Usangu Plains Wetlands: Use of Remote Sensing and GIS as Management Decision Tools. Physics and Chemistry of Earth Parts ABC, 31, 967-975. http://dx.doi.org/10.1016/j.pce.2006.08.007

[11] Kashaigili, J.J. (2008) Impacts of Land-Use and Land-Cover Changes on Flow Regimes of the Usangu Wetland and the Great Ruaha River, Tanzania. Physics and Chemistry of Earth Parts ABC, 33, 640-647. http://dx.doi.org/10.1016/j.pce.2008.06.014

[12] Franks, T. and Cleaver, F. (2007) Water Governance and Poverty a Framework for Analysis. Progress in Development Studies, 7, 291-306. http://dx.doi.org/10.1177/146499340700700402

[13] Kangalawe, R.Y.M., Mwamfupe, D.G. and Mbonile, M.J. (2007). Land Management Systems and Their Environmental Impacts in the Usangu Plains, Tanzania. Journal of the Geographical Association of Tanzania, 32, 15-32.

[14] Njau, P.H., Munishi, P.K.T., Mbije, N.E. and Kadigi, R.M.J. (2013) Challenges and Opportunities for Sustaining the Usangu Wetland in Tanzania. http://www.suaire.suanet.ac.tz:8080/xmlui/handle/123456789/578

[15] Mwakalila, S. (2011) Assessing the Hydrological Conditions of the Usangu Wetlands in Tanzania. Journal of Water Resources Protection, 3, 876-882. http://dx.doi.org/10.4236/jwarp.2011.312097

[16] Mašková, Z., Zemek, F. and Květ, J. (2008) Normalized Difference Vegetation Index (NDVI) in the Management of Mountain Meadows. Boreal Environment Resources, 13, 417-432.

[17] Glenn, E.P., Huete, A.R., Nagler, P.L. and Nelson, S.G. (2008) Relationship between Remotely-Sensed Vegetation Indices, Canopy Attributes and Plant Physiological Processes: What Vegetation Indices Can and Cannot Tell Us about the Landscape. Sensors, 8, 2136-2160. http://dx.doi.org/10.3390/s8042136

[18] Mwanukuzi, P.P.K. (2001) Diagnosis of the Spatial and Temporal Patterns of Dry and Wet Spells due to Land-Atmosphere Water Exchange in the Tropical Savanna of East Africa. PhD Thesis, Clark University, Worcester.

[19] Eastman, R.J. (2006) IDRISI Andes Guide to GIS and Image Processing. Clark University, Worcester.

[20] Ozesmi, S.L. and Bauer, M.E. (2002) Satellite Remote Sensing of Wetlands. Wetlands Ecology and Management, 10, 381-402. http://dx.doi.org/10.1023/A:1020908432489

[21] Thenya, T. (2001) Challenges of Conservation of Dryland Shallow Waters, EwasoNarok Swamp, Laikipia District, Kenya. Hydrobiologia, 458, 107-119. http://dx.doi.org/10.1023/A:1013196500456

[22] Pontius, R.G., Shusas, E. and McEachern, M. (2004) Detecting Important Categorical Land Changes While Accounting for Persistence. Agriculture and Ecosystem Environment, 101, 251-268. http://dx.doi.org/10.1016/j.agee.2003.09.008

[23] Mwita, E.J. (2013) Land Cover and Land Use Dynamics of Semi-Arid Wetlands: A Case of Rumuruti (Kenya) and Malinda (Tanzania). Journal of Geophysics and Remote Sensing, S1, 001.

[24] Ngailo, J.A. (2011) Assessing the Effects of Eviction on Household Food Security of Livestock Keepers from the Usangu Wetlands in SW Tanzania. Livestock Research for Rural Development, 23, 65.

[25] Mwita, E., Menz, G., Misana, S., Becker, M., Kisanga, D. and Boehme, B. (2013) Mapping Small Wetlands of Kenya and Tanzania Using Remote Sensing Techniques. International Journal of Applied Earth Observation and Geoinformation, 21, 173-183. http://dx.doi.org/10.1016/j.jag.2012.08.010

[26] Verschuren, D., et al. (2002) History and Timing of Human Impact on Lake Victoria, East Africa. Proceedings of the Royal Society B: Biological Sciences, 269, 289-294. http://dx.doi.org/10.1098/rspb.2001.1850

[27] Balirwa, J.S., et al. (2003) Biodiversity and Fishery Sustainability in the Lake Victoria Basin: An Unexpected Marriage? BioScience, 53, 703-715. http://dx.doi.org/10.1641/0006-3568(2003)053[0703:BAFSIT]2.0.CO;2

[28] Machiwa, P.K. (2003) Water Quality Management and Sustainability: The Experience of Lake Victoria Environmental Management Project (LVEMP)—Tanzania. Physics and Chemistry of the Earth, Parts A/B/C, 28, 1111-1115. http://dx.doi.org/10.1016/j.pce.2003.08.032

[29] Hecky, R.E., Bootsma, H.A. and Kingdon, M.L. (2003) Impact of Land Use on Sediment and Nutrient Yields to Lake Malawi/Nyasa (Africa). Journal of Great Lakes Research, 29, 139-158. http://dx.doi.org/10.1016/S0380-1330(03)70544-9

[30] Mkanda, F.X. (2002) Contribution by Farmers' Survival Strategies to Soil Erosion in the Linthipe River Catchment: Implications for Biodiversity Conservation in Lake Malawi/Nyasa. Biodiversity and Conservation, 11, 1327-1359. http://dx.doi.org/10.1023/A:1016265715267 
[31] Utafiti: Ziwa Nyasa Linajaa Mchanga na Tope (Lake Nyasa Filled up with Mud) (2). http://www.mwananchi.co.tz/Makala/Utafiti-Ziwa-Nyasa-linajaa-mchanga-na-tope--2-/-/1597592/2552446/-/4jruwr/-/i ndex.html

[32] WakaziZiwa Nyasa Kulipa Gharama za Uchafuzi wa Mazingira. Communities around Lake Nyasa to Pay Environmental Pollution Cost, Jambo, Tanzania. http://www.jambotanzania.com

[33] Erwin, K.L. (2008) Wetlands and Global Climate Change: The Role of Wetland Restoration in a Changing World. Wetlands Ecology and Management, 17, 71-84. http://dx.doi.org/10.1007/s11273-008-9119-1

[34] Kairo, J.G., Dahdouh-Guebas, F., Bosire, J. and Koedam, N. (2001) Restoration and Management of Mangrove Systems-A Lesson for and from the East African Region. South African Journal of Botany, 67, 383-389. http://dx.doi.org/10.1016/S0254-6299(15)31153-4 